Семененко Л. М.

кандидат філологічних наук, доцент КПІ ДВНЗ «Криворізький начіональний університет»

\title{
КОНЦЕПТ БОРОТЬБИ В ЛІРИЦІ ЛЕСІ УКРАЇНКИ
}

У статті розглядаються особливості творчої реалізації концепту боротьби в ліриці Лесі Украӥнки. Автор розкриває специфіку конџепту боротьби в поетичних збірках Лесі Украӥнки. Виокремлюються різні грані творчої інтерпретаиії концепту в ліричних творах поетеси.

Ключові слова: концепт, боротьба, лірика, неоромантизм.

В статье рассматриваются особенности творческой реализации концепта борьбы в лирике Леси Украинки. Автор раскрывает специфику презентации концепта борьбы в поэтических сборниках Леси Украинки. Выделяются разные грани творческой интерпретации конщепта в лирических произведениях поэтесcbl.

Ключевые слова: концепт, борьба, лирика, неоромантизм.

The creative realization's features of the concept of struggle in Lesya Ukrain$\mathrm{ka}$ 's lyrics are discussed in the article. The author reveals the specific presentation of the consept of the struggle in the poetry collections by Lesia Ukrainka. The different faces of the creative interpretation according to the consept are highlighted in the poetess' lyrical works.

Key words: concept, struggle, lyrics, neoromanticism.

Концепт боротьби є актуальним для поетичного доробку Лесі Українки, представленого збірками «На крилах пісень», «Думи і мрії» й «Відгуки», де маніфестується в різних аспектах.

До наукового осмислення поетичного доробку Лесі Українки в різний час зверталися І. Франко, М. Свшан, Д. Донцов, М. Зеров, М. Рильський. На сучасному етапі розвитку літературознавства пропонуються нові шляхи осмислення творчості поетеси, що засвідчено працями В. Агеєвої, І. Бетко, Т. Гундорової, В. Жили, М. Жулинського, А. Криловця, А. Панькова й Т. Мейзерської, О. Турган. Літературознавцями відзначено значущість вказаного концепту для творчого доробку авторки, однак у різний час пріоритетними 
визнавалися різні аспекти мотиву боротьби - від народницьких і неоромантичних до підкреслено символічних та філософських.

Метою статті постає розкриття основного змісту концепту боротьби в ліричних творах Лесі Українки.

Збірку «На крилах пісень» відкриває поетичний цикл «Сім струн», скомпонований за музичним принципом. Показовим $\epsilon$ вірш «Мі» («Колискова»), у якому авторка наголошує на необхідності боротьби 3 долею як неодмінного атрибута людського життя. Переосмислюючи основу фольклорного жанру колискової, поетеса вводить у текст емоційно-оцінні елементи, висуваючи певні вимоги до буття особистості:

\author{
Сором хилитися, \\ Долі коритися! \\ Час твій прийде \\ 3 долею битися, - \\ Сон пропаде... [Українка 1976: 47]
}

Актуальними для народницького дискурсу збірки є традиційні заклики «орати рідні перелоги», «не забути в самотині країну свою», що відбивають творчі пріоритети авторки, сформовані на час публікації збірки. Поетеса оцінює власний спів як «тихий» i «несмілий», проте чітко окреслює завдання поетичної творчості:

Я йду шляхом, пісні свої співаю;

Та не шукайте в них пророчої науки,

$\mathrm{Hi}$, голосу я гучного не маю!

Коли ж хто сльози ллє $з$ тяжкої муки, -

Скажу я: «Разом плачмо, брате мій!»

3 його плачем я спів з'єднаю свій...

[Українка 1976: 87] 
У поезіях циклу «Сльози-перли» специфічно поєднуються мотив плачу над недолею (передусім недолею України-батьківщини) з декларацією активної, рішучої боротьби за волю. Ставлення до України Леся Українка окреслює як виразно патріотичне, таке, що потребує активного втручання в їі долю. Подібний підхід корелює 3 традиційним для поезії попередників, зокрема Т. Шевченка бажанням повністю віддаватися боротьбі за визволення України. При цьому акт боротьби осмислюється як єдино можливий вибір особистості:

Як же повстане - їй не буде впину,
Заснути знов, як перш, вона не зможе,
Вона боротись буде до загину:
Або загине, або переможе.
Або погибель, або перемога -
Сі дві дороги перед нами стане...
Котра з сих двох нам судиться дорога?
Дарма! повстанем, бо душа повстане

[Українка 1976: 74].

Продовжуючи народницьку традицію, у поезії «Співець» Леся Українка вдається до детального опису українського пейзажу, однак при цьому основною залишається декларація мистецького служіння й вірності батьківщині:

Чом я не маю огнистого слова,

Палкого, чому?

Може б, та щира, гарячая мова

Зломила зиму!..

...Та хоч би й крила мені солов'їні,

І воля своя, -

Я б не лишила тебе в самотині,

Країно моя! [Українка 1976: 63] 
Отже, у віршах збірки концепт боротьби осмислюється передусім як поєднання громадянського й особистісного аспектів. При цьому громадянський зміст часто актуалізує народницькі гасла й відповідні коди («орати рідні перелоги» тощо), а лірична героїня позиціонується як активна мисляча особистість, здатна не лише до «плачу», а й до рішучої боротьби за проголошені цінності. Класичними прикладами в цьому плані $\epsilon$ вірші «Contra spem spero» та «Досвітні огні».

Збірка «Думи і мрії» стала своєрідним явищем в українській поезії кінця XIX - початку XX ст. Переосмислюючи народницькі ідеали, поетеса по-новому актуалізує в поезіях збірки дискурси громадянської та особистісної боротьби, розкриваючи їх передусім у поетичних циклах. Неволя викликає відповідні настрої, що яскраво виражено зокрема в поезії «Хвилина розпачу» (цикл «Невільничі пісні»):

О горе тим рукам, що звикли у неволі

Носить кайдани ржаві та важкі,

На волю вирвуться, і там бридкі мозолі

Їм нагадають, хто вони такі.

О горе тим, що мають душу чесну!

Коли вони ще вірять у богів,

Благати мусять силу ту небесну:

«Пошли нам, боже, чесних ворогів!»

[Українка 1976: 138]

У цій поезії висловлюється навіть готовність відкинути такі значущі для доробку поетеси цінності, як честь та сумління задля визволення з неволі-темниці:

О горе нам усім! Хай гине честь, сумління, Аби упала ся тюремная стіна!

Нехай вона впаде, і зрушене каміння

Покриє нас і наші імена [Українка 1976: 138-139]. 
Поруч із традиційним осмисленням громадянського обов'язку, поетеса звертається й до неоромантичного підходу до ідей служіння людям. Важливим образом, що актуалізує в цьому ракурсі концепт боротьби, постає в збірці міфологічний образ Прометея, представлений у творах «Fiat nox!» (цикл «Невільничі пісні») та «Іфігенія в Тавриді» (цикл «Кримські відгуки»). У поезіï «Fiat nox!» використана опозиційна пара світло / темрява, що своєрідно віддзеркалює опозицію боротьби / бездіяльності:

$\mathrm{O}$, не один нащадок Прометея

Блискучу іскру з неба здобував [Українка 1976: 141].

Надалі акцентується трагічна бездіяльність тих, хто відкидає спадок Прометея, відмовляючися від боротьби (світла):

Брати мої, нащадки Прометея!

Вам не орел розшарпав груди горді, -

Бридкі гадюки в серце уп'ялись.

Ви не приковані на тій кавказькій кручі,

Що здалека сіяє сніжним чолом,

Про в’язня звістку людям даючи!

$\mathrm{Hi}$, ви поховані в землянках, звідки навіть

Не чутно брязкоту кайданів, ні стогнання, Ні непокірних слів... [Українка 1976: 142]

На думку авторки, життя в темряві - життя без боротьби повинне закінчитися смертю.

У сцені «Іфігенія в Тавриді» Леся Українка також звертається до образу нащадка Прометея, розкриваючи його через призму бачення Іфігенії, яка пожертвувала собою заради рідної Еллади. Апелюючи до грецького міфу, авторка оригінально осмислює долю Іфігенії, зображує іiї життя та внутрішній світ, сповнений туги за батьківщиною й рідними. Перенесена волею богині в чужу краї- 
ну, позбавлена зв'язку з батьківщиною та рідними, Іфігенія перебуває у відчаї і прагне власної смерті, однак опускає меч:

$\mathrm{Hi}$, се не варт нащадка Прометея!

Коли хто вмів одважно йти на страту,

Той мусить все одважно зустрічать!

Коли для слави рідної Еллади

Така потрібна жертва Артеміді,

Щоб Іфігенія жила в цій стороні

Без слави, без родини, без імення,

Хай буде так.

Аргосе, рідний мій!

Воліла б я сто раз умерти,

Ніж тута жити! Води Стікса й Лети

Не згасять спогадів про любий рідний край!

Тяжкий твій спадок, батьку Прометею!

[Українка 1976: 142]

У вірші «...Порвалася нескінчена розмова...» аспект звільнення в боротьбі набуває дещо іншого звучання. Звуковий образ брязкоту кайданів трактується як такий, що повинен розбудити людей, закликати їх до боротьби, у якій не потрібними будуть слова туги, суму:

Нехай же дзвонять голосно кайдани, Не буду заглушать. Коли б могли

Вони збудить луну і розтроюдить рани

В серцях людей, що мохом поросли;

Коли б кайданів брязкіт міг ударить

Перуном в тії заспані серця,

Спокійні чола соромом захмарить

I нагадать усім, що зброя жде борця;

Коли б та зброя здійнялась до бою,

Загомоніла б так, мов туча градова, - 
Тоді б замовкли вже самі собою

Кайданів брязкіт і такі слова [Українка 1976: 172].

Позиціонування сильної, здатної до боротьби особистості, характерної для неоромантичної концепції творчості, відбувається в збірці послідовно. Зокрема у вірші «О, знаю я, багато ще промчить...» «голос і долю» такої особистості письменниця порівнює 3 гартуванням металу для мечів:

Я знаю се і жду страшних ночей,

I жду, що серед них вогонь той загориться,

Де жевріє залізо для мечей,

Гартується ясна і тверда криця...

Коли я крицею зроблюсь на тім вогні,

Скажіть тоді: нова людина народилась...

[Українка 1976: 139-140].

Таким чином відмова від боротьби однозначно засуджується авторкою, натомість у поезіях збірки поетизуються воля до боротьби та вибір сильної особистості.

Леся Українка активно звертається до символіки кольорів, інтерпретуючи їх як атрибути концепту боротьби. У різноманітних зіставленнях вона застосовує, наприклад, червоний колір, використовуючи його для унаочнення образів вогню, пожежі, квітів, крові.

Так, у поезії «Уривки $з$ листа» (цикл «Кримські відгуки») подається образ червоної квітки, яка росте високо в горах:

Камінь пробила вона, той камінь, що все переміг, Що задавив і могутні дуби,

І терни непокірні.

Квітку ту вченії люди зовуть Saxifraga, Нам, поетам, годиться назвати іiі ломикамінь

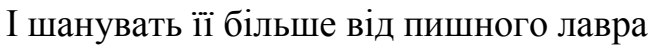

[Українка 1976: 158]. 
Поезія «У чорную хмару зібралася туга моя...» (цикл «Мелодії) бачиться як своєрідний синтез концепту боротьби, реалізований у постаті ліричної героїні. Пережиті «хвилини розпачу», розчарування й плачу замінюються на готовність до боротьби, яка виливається в поетизації протистояння життєвим бурям:
Весняная сила в душі моій грає,
іiї не зломили зимові морози міцні,
іiі до землі не прибили тумани важкі,
iii не розбила і ся перелітная буря весняна.
Нехай там збирається гірша, страшніша негода, Нехай там узброїться в гостру, огненную зброю, Я вийду сама проти неї
І стану - поміряєм силу! [Українка 1976: 134]

Прийом повтору підкреслює водночас суворість і багатогранність життєвих випробувань та непорушну волю до боротьби, притаманну ліричній героїні вірша. Використання нестягненої форми прикметників (весняная сила, перелітная буря, огненную зброю) надає поезії урочистого, підкреслено піднесеного звучання.

Таким чином у збірці «Думи і мрії» домінують неоромантичні підходи в розкритті мотивів суспільної й особистісної боротьби.

Збірка «Відгуки» відкривається поезіями, які презентують мотив боротьби. У поезіях циклу «Невільничі пісні» гостро звучать мотив поневолення та заклик до боротьби за волю. Перші два вірші циклу «Єврейські мелодії» (《Як Ізраїль діставсь ворогам у полон...», «Ереміє, зловісний пророче в залізнім ярмі!») відзначаються надзвичайно високою концентрацією опозиції воля / неволя, реалізованої в образах «подоланих борців», арфи, очоленої на вербі, «залізного ярма», «лютого жалю», «серця 3 твердого кришталю» тощо. Близький до цих поезій вірш «Епілог», у якому Леся Українка звернулася до зображення різних поколінь борців за волю. При цьому основну увагу поетеса приділяє розкриттю почуттів молодого покоління, що не має сили старших і може тільки мріяти: 
Чи сльози, чи квітки від нас належать вам, підкошені в розцвіті сил герої?

Коли б то так судилося і нам спалити молодість і полягти при зброї!

[Українка 1976: 185]

Звертаючись до антитези, поетеса наголошує на розриві старшого й молодшого поколінь борців за волю:

Старі мечі поржавіли, - нових

Ще не скували молодії руки;

Були поховані всі мертві, а в живих

Не бойової вчитись ми науки [Українка 1976: 185].

Показовою в контексті теми бачиться поезія «Завжди терновий вінець», у якій репрезентовано мотив нездатності до боротьби як мотив марної покори:

Хто ж без одваги й без волі

на путь заблукався згубливу, плачучи гірко від болю, дає себе тернові ранить, сили не маючи стільки, аби від тернів боронитись, боже, пожальсь тої крові, що марно колючки напоїть! [Українка 1976: 190]

Значне місце в збірці приділено мотиву мистецтва як такому, що органічно поєднується з концептом боротьби.

Промінням ясним, хвилями буйними, прудкими іскрами, летючими зірками, палкими блискавицями, мечами 
хотіла б я вас виховать, слова!

Щоб ви луну гірську будили, а не стогін, щоб краяли, та не труїли серце, щоб піснею були, а не квилінням [Українка 1976: 191].

Отже, мотив боротьби є значущим для цілого поетичного доробку Лесі Українки й набуває в різних поезіях різного забарвлення - від глибоко особистісного до суспільно-політичного та філософського. Як основні його грані окреслимо такі:

- народницькі домінанти розкриття мотиву боротьби в збірці «На крилах пісень»;

- неоромантичний контекст боротьби в збірці «Думи і мрії»;

- утвердження ідей боротьби за загальнолюдські цінності в збірці «Відгуки».

\section{БІБЛІОГРАФІЯ}

Агеєва 2001 - Агеєва В. П. Поетеса зламу століть: Творчість Лесі Українки в постмодерній інтерпретації : монографія / В. Агеєва. - К. : Либідь, 2001. - 264 c.

Донцов 1994 - Донцов Д. Поетка українського рісорджіменту // Українське слово : хрестоматія української літератури та літературної критики XX ст. : у 3 т. T.1. - К. : Рось, 1994. - С. 149-183.

Зеров 1990 - Зеров М. К. Леся Українка / М. Зеров. // Твори : у 2 т. - К. : Дніпро, 1990. - T. 2. - C. 359-401.

Жила 1993 - Жила В. Прометеївські образи і мотиви в творчості Лесі Українки // Сучасність. - 1993. - № 4. - С. 118-127.

Паньков 1996 - Паньков А., Мейзерська Т. Поетичні візії Лесі Українки : онтологія змісту і форми. - Одеса : Астропринт, 1996. - 76 с.

Українка 1976 - Українка Леся. Зібрання творів : у 12 т. - Т. 1. - К. : Наукова думка, 1976. - 340 с. 